COVID-19

\title{
Problem Semiotika Ruang Pasar Tradisional Yogyakarta Dan Solusi Desain Interior Berkelanjutan
}

\author{
Setya Budi Astanto \\ Institut Seni Indonesia Yogyakarta \\ setyabudi.astanto@gmail.com
}

\begin{abstract}
Abstrak
Pasar tradisional adalah tiga layanan publik yang tidak ditutup selama pandemi COVID-19, selain Rumah Sakit dan Stasiun Pengisian Bahan Bakar Umum. Regulasi social distancing hampir tidak berlaku di pasar tradisional. Ada apa dengan pasar tradisional di Yogyakarta, betulkah pasar tradsional tidak punya adat-istiadat peraturan turun temurun tentang proksemika. Kebaruan ukuran jarak interaksi antar manusia saat pandemic COVID-19 akan dianalisa menggunakan metode desain berkelanjutan biomimikri. Mencari sumber solusi desain berdasarkan sistem alam semesta. Manfaat penelitian adalah menemukan jarak new normal atau new hidden dimension yang dimiliki oleh kearifan lokal masyarakat Yogyakarta. Berguna bagi ilmu desain pasar new normal dan pasar di masa depan.
\end{abstract}

Kata kunci: covid-19, desain berkelanjutan biomimikri, semiotika ruang, pasar tradisional.

\begin{abstract}
A tradisional markets are three public services that were not closed during Covid-19 Pandemic besides hospitals and gas stations or fuel stations. Regulations of social distancing are not almost applicable at tradisional market. What happened to tradisional market in Yogyakarta, is it true that tradisional market have no regulation or behaviour which relate to proxemics. A new normal on spaces in human interaction during the covid-19 pandemic will be analyzed with sustainable biomimikri design methods to find resources of design solution base on system of universe. The aim of this study is to find new normal space or new hidden dimention which is own by Yogyakarta citizen local wisdom. This study will be useful for market in new normal and the future market design.
\end{abstract}

Keywords: covid-19, biomimicry sustainable design, space semiotics, traditional markets

\section{Pendahuluan}

Data Ikatan Pedagang Pasar Indonesia (IKAPPI) menyebutkan sebanyak 1.392 pedagang pasar tradisional di Indonesia terpapar virus Corona (Reynaldi 22/9/2020). Penanggulangan COVID-19 menemui anti klimak di pasar tradisional, cuci tangan dengan sabun, mengenakan masker tidak sepenuhnya dipatuhi. Pasar tradisional berpotensi menjadi epicentrum penyebaran virus Corona di masa pandemi COVID-19. Fasilitas publik rumah sakit, apotek dan Stasiun Pengisian Bahan Bakar Umum, pasar tradisional termasuk yang masih tetap beroperasi. Social Distancing dengan menjaga jarak antar manusia sejauh 6 feet atau sekitar $180 \mathrm{~cm}$ sesuai standart WHO menemukan kegagalan secara brutal di pasar tradisional Yogyakarta serta pasar tradisional pada umumnya di Indonesia. Pasar tradsional di kota Padang Sumatra Barat bahkan berubah menjadi pusat epicentrum penyebaran virus Corona. 
Penanggulangan COVID-19 antiklimak di pasar tradisional, cuci tangan dengan sabun, mengenakan masker tidak sepenuhnya dipatuhi. Aktivitas berniaga di pasar rawan terjadi perpindahan virus Corona, sentuhan tangan dan perpindahan uang ataupun barang dagangan. Pelanggaran social distancing di pasar tradsional berpotensi menimbulkan problem ikutan, karena hampir semua pengunjung pasar akan pulang ke rumah masing- masing, barang belanjaan akan di distribusikan kepada lebih banyak orang begitu seterusnya. Pemerintah daerah beserta pemegang regulasi pasar tradisonal terkesan canggung bersentuhan dengan kebiasaan berniaga di pasar tradisional. Stigma pasar tradisional tempat orang berpendidikan rendah dan berasal dari golongan ekonomi menengah ke bawah menjadi alasan tidak tertulis pembiaran semua pelanggaran social distancing. Gerakkan serentak stay at home dan work from home apalagi social distancing menemukan fenomena ganjil di pasar tradisional Yogyakarta.

Edward T Hall dengan proxemikanya membuat klasifikasi jarak antar manusia saat berinteraksi sosial menjadi jarak intim, personal, sosial dan jarak publik. Semua klasifikasi runtuh saat pandemi COVID-19, semua aktivitas manusia ditempat publik dibatasi dan diatur ulang oleh organisasi kesehatan dunia WHO. Tradisi dan budaya serta adat-istiadat sebuah masyarakat tunduk pada keselamatan nyawa dan kesehatan. Fenomena menarik di kota budaya Yogyakarta yang terkenal punya jarak interaksi sosial yang intim. Sejarah saat ini mencatat betapa jarak interaksi antar manusia begitu sangat penting sekaligus berbahaya Warisan budaya masyarakat tropis Yogyakarta dalam berniaga berawal dari prinsip utama di bawah pohon teduh, tidaklah mengherankan jika sebagian pasar tradsional diberi nama sesuai pohon yang menaunginya.

Pasar Beringharjo dengan fasilitas awal pohon Beringin yang besar, Pasar Ngasem tempat pedagang bernaung di bawah teduhnya pohon Asem, begitu juga pasar Sawo, pasar Talok dan lain-lain. Semakin banyak pohon besar akan semakin banyak pasar tradisional di Yogyakarta. Hingga modernisasi mengubah prinsip pasar dari sistem naungan menjadi sistem kapling luasan lahan lantai keramik. Mengubah facade wajah pasar dari era bersih rindang sejuk menjadi pasar kios-kios bermahkota tempat sampah raksasa di depan setiap pasar. Modernisasi pasar tradisonal berdampak pada proxemika atau jarak manusia berinteraksi di dalam ruang. Semakin rapat jarak antar manusia maka saat terjadi pandemia atau patologi maka akan semakin besar potensi pasar tradisional menjadi epicentrum penyebaran virus COVID-19. Hasil penelitian desain berkelanjutan metode Biomimikri mencari solusi desain new normal. Bersumber dari sistem kearifan lokal dan fenomena perubahan ekstrem Semiotika Ruang. Terutama saat terjadi patologi atau wabah dan kerumunan. Pandemi COVID-19 merupakan problem sekaligus solusi redesain new normal pasar tradisional berbasis kearifan lokal.

\section{Metode}

Penelitian ini merupakan tindak lanjut dari pengamatan peneliti terhadap problem umum di area pasar tradisional yang juga pernah diteliti pada tahun 2014 dengan judul "Kearifan Lokal Desain Interior Biomimikri Pasar Telo Karangkajen Yogyakarta" Study Kasus: Program Renovasi Pasar Tradisional oleh Dinas Pengelola Pasar Yogyakarta. Dinas Pengelola pasar beserta pemangku kebijakan tata kota tidak jarang mengalami problem untuk memberi solusi desain pada saat harus merenovasi atau membangun pasar tradsional di Yogyakarta. Problem terbesar adalah terhapusnya artefak pasar tradisional sebagai akar dari pusat kebudayaan sebuah kota. Renovasi sering tidak beda dengan membuat kios batu bata tanpa memberi benang merah terhadap kebudayaan berniaga yang mungkin suatu saat akan menjadi pedoman tata kelola pasar modern yang lebih baik dan bermartabat.

Aktivitas manusia di area publik dibatasi, diatur ulang oleh organisasi kesehatan dunia WHO. Tradisi dan budaya serta adat-istiadat tunduk dengan keselamatan dan kesehatan hidup antar manusia, Sejarah mencatat betapa jarak interaksi antar manusia saat pandemi begitu berbahaya, tidak terkecuali di pasar tradisonal Yogyakarta. Pasar Beringharjo dan pasar Ngasem Serta Pasar Legi Yogyakarta akan menjadi lokasi dan objek penelitian. Ketiga pasar tradisional tersebut 
merupakan pasar tradisonal yang saat ini dokumentasinya relatif masih bisa terlacak. Sejarah pasar tradisonal yang menjadi lokasi penelitian sama-sama memiliki nama berdasar site lanscape, Sesuatu yang khas sekaligus mencerminkan kearifan lokal budaya luhur masyarakat di Yogyakarta. Sejarah pasar-pasar tradisional yang berkembang besar dan bertahan hingga saat ini ditandai dengan nama pohon besar yang menaungi para pedagang saat pertama kali pasar terbentuk. Seperti pasar besar Beringharjo sejarahnya bermula dari para pedagang yang menjajakan dagangannya di bawah pohon Beringin besar. Pasar Ngasem sebagai wisata dan budaya namanya diambil dari teduhnya pohon Asem yang menaungi saat berdagang. Nama Pasar Legi adalah sekumpulan pedagang setiap hari pasaran Legi dibawah pohon Beringin, dulunya dikenal dengan Pasar Ringin, karena nama pasar Beringin sudah identik dengan pasar yang lebih besar pasar Beringharjo maka nama pasar Legi dipilih sebagai nama pasar yang dulunya di bawah pohon Beringin tersebut.

Ketua peneliti menyiapkan perangkat penelitian dengan panduan semiotika ruang menurut praxemikanya Edward T. Hall untuk melihat fenomena jarak antar manusia. Anggota penelitian akan mengamati dan mencatat penomena perubahan jarak antar manusia merupakan kategori semiotika ruang atau proxemika yang pernah dibuat oleh Edward $\mathrm{T}$ Hall dengan jarak antar manusia di pasar saat terjadi pandemi COVID-19. Anggota penelitian juga melakukan pendataan tentang kegagalan jaga jarak dan lain-lain. Anggota penelitian akan mengamati dan mencatat serta berusaha melakukan wawancara tentang alasan pelanggaran social distancing.

Penelitian berjudul COVID-19 Problem Semiotika Ruang Pasar Tradsional Yogyakarta dan Solusi Desain Interior Berkelanjutan menggunakan model kualitatif, melalui fokus kajian tentang efisiensi dan efektivitas penerapan prinsip desain berkelanjutan biomimikri yang tidak memanfaatkan perhitungan dalam angka, melainkan melihat kenyataan yang ada di lapangan, kemudian menyajikan temuan tersebut dalam bentuk deskriptif analitik. "Menurut Bogdan dan Taylor, penelitian kualitatif merupakan prosedur yang memproduksi data- data deskriptif berupa data-data tertulis atau lisan dari orang-orang dan perilaku yang diamati." (Moleong, 2009:4).

Data yang dikumpulkan oleh anggota dan ketua selanjutnya akan dipilah menurut klasifikasi semiotika ruang atau proxemika menjadi jarak intim, personal, sosial dan jarak publik, jarak anjuran WHO, Jarak kultural Yogyakarta. Data terpilih di analisa oleh ketua penelitian bersama anggota mengunakan kesesuaian atau kesuksesan jarak social distancing anjuran WHO dan pedoman Mabes POLRI menghadapi COVID-19. Faktor apa saja yang membuat problem kegagalan pelaksanaan social distancing anjuran WHO dan faktor apa yang membuat program penanggulanga COVID-19 sukses di pasar tradsional Yogyakarta.

Penelitian berjudul "COVID-19 Problem Semiotika Ruang Pasar Tradisional Yogyakarta Dan Solusi Desain Interior Berkelanjutan" menggunakan metode penelitian kualitatif. Hal ini disebabkan karena kajian tentang efisiensi dan efektivitas penerapan prinsip desain berkelanjutan biomimikri tidak memanfaatkan perhitungan dalam angka, melainkan melihat kenyataan yang ada di lapangan, kemudian menyajikan temuan tersebut dalam bentuk deskriptif analitik. "Menurut Bogdan dan Taylor, penelitian kualitatif merupakan prosedur yang memproduksi data deskriptif berupa data-data tertulis atau lisan dari orang-orang dan perilaku yang diamati." (Moleong, 2009:4). Metode pada penelitian ini lebih bertujuan untuk mengetahui tentang bagaimana kearifan lokal masyarakat Yogyakarta dalam berdagang sejak awal sejarah terjadinya pasar sebagai penerapan prinsip desain berkelanjutan biomimikri.

Data penelitian ini bersumber dari aktifitas di lapangan, sumber tertulis dan sumber lisan. Pengumpulan data-data dilakukan secara langsung (data primer) maupun tidak langsung terhadap sumber aslinya (data sekunder). Selanjutnya data yang berupa wujud desain itu akan direduksi atau dipilih menggunakan teori penerapan prinsip-prinsip desain berkelanjutan biomimikri yang bersumber pada buku terbitan tahun 2008 yang berjudul Environmentally Responsible Design: Green and Sustainable Design for Interior Designer. Semua data baik yang tertulis maupun lisan, selanjutnya akan diolah dan dianalisis serta disajikan dalam bentuk deskriptif analitik. Dalam 
penelitian ini untuk melakukan analisa data jarak interaksi manusia saat berdagang di pasar tradsional era COVID-19 maupun era new normal COVID-19.

Selanjutnya data jarak interaksi antar manusia saat berdagang di pasar tradsional Yogyakarta dibandingkan dengan anjuran WHO tentang jarak social distancing atau jarak aman era pandemic COVID-19. Kemudian dibuat pola pelanggarannya , untuk dicari apa penyebab pelanggaran jarak aman sebagai problem sering munculnya COVID-19 kluster pasar.

Populasi dan sample pada penelitian ini adalah pasar Beringharjo dan Pasar Ngasem yang legendaris baik saat ini maupun awal mula terjadinya pasar tersebut. Teknik pengumpulan data menurut Soedarsono "Pengumpulan data dalam penelitian kualitatif dapat diperoleh melalui beberapa sumber data". (Soedarsono, 1999:126). Sumber data kualitatif yang bisa digunakan dalam penelitian seni rupa adalah sumber pengamatan perilaku, sumber tertulis, sumber lisan, dan artefak. Pengumpulan data-data tersebut dapat dilakukan secara langsung (data primer) maupun tidak langsung terhadap sumber aslinya (data sekunder).

\section{Metode Studi Pustaka}

Studi pustaka merupakan sebuah metode pencarian data yang bersumber dari buku-buku, majalahmajalah ilmiah, dan sumber-sumber tertulis lainnya. Disini peneliti melakukan pembacaanpembacaan terhadap artikel yang memuat berbagai hal yang berhubungan dengan sejarah dulu hingga kini pasar tradisional Yogyakarta. Sedangkan buku-buku yang bersifat teoritis untuk memperoleh informasi mengenai desain interior berkelanjutan biomimikri. Penerapan prinsipprinsip desain berkelanjutan sebagai wujud tanggung jawab desainer interior dan keberpihakan padalingkungan alam.

\section{Metode Wawancara}

Interview dapat dipandang sebagai metode pengumpulan data dengan jalan tanya jawab sepihak yang dikerjakan dengan sistematik dan berlandaskan kepada tujuan penyelidikan. Pada umumnya dua orang atau lebih hadir secara fisik dalam proses tanya jawab itu, dan masing-masing pihak dapat menggunakan saluran-saluran komunikasinya secara wajar dan lancar. (Sutrisno,1980:193). Wawancara akan dilakukan penulis dengan beberapa pemerhati sejarah kota Yogyakarta, masyarakat penggunjung pasar, pedagang pasar, ahli tata hutan kota Yogyakarta, desainer dan mahasiswa. Wawancara ini bertujuan mengetahui seberapa jauh mereka memahami bahwa pelanggaran jarak aman saat berdagang bisa dicegah dengan desain yang sudah dimiliki oleh masyarakat Yogyakarta sejak awal berdirinya pasar-pasar legendaris.

\section{Metode Observasi}

Observasi langsung pada aktivitas interaksi manusia dalam berdagang dan jarak yang ditimbulkan oleh desain pasar saat ini. Observasi merupakan metode ilmiah yang diartikan sebagai pengamatan pencataan dengan sistematik fenomena-fenomena yang diselidiki. Dalam arti luas observasi sebenarnya tidak hanya terbatas pada pengamatan yang dilakukan baik secara langsung maupun tidak langsung. Pengamatan yang langsung misalnya; questionaire. (Sutrisno, 1980:136) Metode observasi dipakai untuk melihat dan mengamati sendiri serta mencatat informasi-informasi dari informan, sehingga memungkinkan peneliti mencatat situasi yang berkaitan dengan pengetahuan yang diperoleh langsung dari data. Selain itu, observasi dengan melihat penerapan desain interior Biomimikri saat manusia berinteraksi dalam berdagang serta jarak yang ditimbulkannya sehingga COVID-19 kluster pasar makin sering terjadi. Semua pengamatan secara langsung untuk memperoleh gambaran nyata dari objek penelitian.

\section{Metode Analisis Data}

Metode analisis data yang digunakan dalam penelitian ini adalah metode analisis data kualitatif yang disajikan secara deskriptif. Analisis data kualitatif adalah upaya yang dilakukan dengan cara 
mengorganisasikan data, memilah-milah data menjadi satuan yang dapat dikelola, mensintesiskannya, mencari dan menemukan pola, menemukan apa yang penting dan apa yang dipelajari, dan memutuskan apa yang dapat diceritakan kepada orang lain. (Moleong, 2009:248).

Proses analisis data dalam penelitian ini meliputi beberapa tahapan. Pertama adalah indentifikasi data, mengumpulkan dan menyeleksi data atau menyisihkan data yang tidak relevan dan kurang berkontribusi terhadap kebutuhan pokok bahasan baik berupa data verbal dan data visual, baik yang diperoleh melalui studi pustaka, observasi, maupun wawancara. Sehingga data yang disajikan hanya data yang menunjukkan potensi jarak aman dalam berdagang di pasar tradsional Yogyakarta. Tahap kedua adalah analisis penerapan desain interior berkelanjutan biomimikri untuk melihat rekayasa desain Biomimikri sesuai teori-teori yang telah ditetapkan sebelum terjadi COVID-19 dan dikaji data tentang sejarah awal terbentuknya desain pasar di Yogyakarta, dan selanjutnya disajikan dalam bentuk karya tulis ilmiah.

\section{Pembahasan}

Hasil penelitian dengan metode analisa desain interior berkelanjutan menunjukkan bahwa makin seringnya timbul klaster pasar tradisional di Yogyakarta salah satunya disebabkan desain pasar yang memicu pelanggaran jarak aman sesuai perintah WHO. Social distancing dengan jarak interaksi 60 feet atau setara $180 \mathrm{~cm}$ sangat sulit dilakukan dengan kondisi desain pasar yang berupa kios-kios kecil dengan jalan sempit dibawah gedung monoblok layaknya Pasar Inpres pada umumnya. Metode desain berkelanjutan Biomimikri menjadikan sistem alam semesta harus menjadi ide dan inspirasi bagi solusi desain. Pasar tradisional saat penelitian ini berlangsung potensial menimbulkan kluster COVID-19. Jarak sesuai anjuran WHO sangat sulit dicapai. Tidak hanya karena ruang yang sempit, tetapi pola desain yang berjejer memicu pelanggaran jarak aman atau social distancing. Penelitian menemukan menarik dari desain dan pola pasar tradisional saat pertama kali terjadi secara alamiah sesuai sistem alam semesta atau desain Biomimikri. Sejarah awal pasar-pasar legendaries di Yogyakarta selalu diawali adanya pohon besar yang teduh untuk melakukan aktivitas berdagang. Pohon teduh memungkinkan pembeli nyaman antri, pedagang juga mempunyai jarak sesuai standart WHO saat COVID-19 karena terpisah oleh pohon besar, masing-masing pedagang mampu mempertahankan jarak aman berkat aanya pohon besar yang mereka kelilingi.

COVID-19 menular melalui virus yang terbawa dan menetes melalui cairan saat batuk atau bersin, jarak tular sangat dipengaruhi oleh jarak manusia penular dan tertular. Menjaga jarak merupakan salah satu solusi. Desain interior berkelanjutan Biomimikri merupakan solusi desain untuk menjaga jarak saat transaksi dan interaksi di pasar tradisional. Kearifan lokal yang terkandung dalam sejarah berdirinya pasar-pasar besar di Yogyakarta menunjukkan adanya desain pasar yang mempunyai lay-out melingkari pohon besar dengan naungan rindangnya dedaunan, seperti pohon Beringin yang kini menjadi pasar besar Beringharjo Yogyakarta, atau pohon Asem yang kini menjadi Pasar Wisata Budaya Ngasem Tamansari Yogyakarta. Desain berkelanjutan Biomimikri memberikan inspirasi desain pasar tradisional yang melingkari pohon besar asehingga jarak proxemika terjaga sesuai SOP WHO yaitu 60 inc atau $180 \mathrm{~cm}$ antar manusia. Desain melingkar sesuai sistem naungan pohon besar ini bisa jadi alternatif desain pasar masa depan untuk mencegah penularan virus COVID-19. Menggantikan desain pasar tradsional dengan desain blok layaknya desain Pasar Inpres dan Superblock pasar modern. 


\section{Simpulan}

Tabel 1. analisa jarak Semiotika Ruang atau Proksemika berdasar lay-out pasar

\begin{tabular}{|c|c|c|c|c|c|}
\hline NO & $\begin{array}{l}\text { NAMA } \\
\text { PASAR }\end{array}$ & $\begin{array}{l}\text { TYPE } \\
\text { LAY- } \\
\text { OUT }\end{array}$ & $\begin{array}{c}\text { JARAK } \\
\text { PROKSEMIKA } \\
\text { PEDAGANG }\end{array}$ & $\begin{array}{c}\text { JARAK } \\
\text { PROKSEMIKA } \\
\text { PENGUNJUNG }\end{array}$ & $\begin{array}{c}\text { STANDART } \\
\text { JAGA } \\
\text { JARAK } \\
\text { WHO } 6 \\
\text { kaki/180CM }\end{array}$ \\
\hline 1 & $\begin{array}{l}\text { Beringharjo } \\
1925-2020\end{array}$ & Blok & $\begin{array}{c}\text { Jarak personal } 4 \\
\text { kaki }\end{array}$ & $\begin{array}{l}\text { Jarak intim-jarak } \\
\text { personal }\end{array}$ & $\begin{array}{c}\text { Tidak sesuai } \\
\text { protokol } \\
\text { COVID-19 } \\
\end{array}$ \\
\hline 2 & $\begin{array}{l}\text { Beringin } \\
\text { Harjo } \\
1758-1925\end{array}$ & $\begin{array}{l}\text { Melingkari } \\
\text { pohon } \\
\text { Beringin } \\
\text { besar }\end{array}$ & $\begin{array}{c}\text { Jarak Sosial 4-10 } \\
\text { kaki }\end{array}$ & $\begin{array}{c}\text { Jarak Sosial 4-10 } \\
\text { kaki }\end{array}$ & $\begin{array}{c}\text { Sesuai } \\
\text { protokol } \\
\text { COVID-19 }\end{array}$ \\
\hline 3 & $\begin{array}{l}\text { Ngasem } \\
1960-2020\end{array}$ & Blok & $\begin{array}{c}\text { Jarak personal } 4 \\
\text { kaki }\end{array}$ & $\begin{array}{l}\text { Jarak intim-jarak } \\
\text { personal }\end{array}$ & $\begin{array}{c}\text { Tidak sesuai } \\
\text { protokol } \\
\text { COVID-19 }\end{array}$ \\
\hline 4 & $\begin{array}{l}\text { Ngasem } \\
1809-1960\end{array}$ & $\begin{array}{c}\text { Melingkari } \\
\text { Pohon } \\
\text { Asem } \\
\text { Besar }\end{array}$ & $\begin{array}{c}\text { Jarak Sosial 4-10 } \\
\text { kaki }\end{array}$ & $\begin{array}{c}\text { Jarak Sosial 4-10 } \\
\text { kaki }\end{array}$ & $\begin{array}{c}\text { Sesuai } \\
\text { protokol } \\
\text { COVID-19 }\end{array}$ \\
\hline
\end{tabular}

(Astanto, 2020)

Rencana penelitian berikutnya membuat konklusi tentang ilmu baru proksemika atau semiotika ruang bernama new hidden dimension era New Normal COVID-19. Metode analisa desain interior berkelanjutan Biomimikri menunjukkan bahwa makin seringnya timbul klaster pasar tradisional di Yogyakarta salah satunya disebabkan desain pasar yang memicu pelanggaran jarak aman sesuai perintah WHO. Maka rencana penelitian akan mulai fokus kepada mencari potensi jarak aman new normal berbasis kearifan lokal terutama sejarah awal berdirinya pasar tradsional di Yogyakarta. Social distancing dengan jarak interaksi 60 feet atau setara $180 \mathrm{~cm}$ sangat sulit dilakukan dengan kondisi desain pasar yang berupa kios-kios kecil dengan jalan sempit dibawah gedung monoblok layaknya Pasar Inpres pada umumnya.

\section{Daftar Pustaka}

Dodsworth, Sion. (2009), The Fundamental of Interior Design, AVA Publishing, Switserland.

Eco, Umberto. (1976), A Theory Of Semiotics, Indiana University Press.

Frick, Heinz. (1997), Pola Struktural dan Teknik Bangunan di Indonesia, Suatu pendekatan arsitektur Indonesia melalui pattern language secara kontruktif dengan contoh arsitektur Jawa Tengah.Penerbit Kanisius, Yogyakarta.

Gardjito, Murdijati. et al, (2017) Kuliner Yogyakarta Pantas Dikenang Sepanjang Masa, Gramedia, Jakarta. 
Hall, Edward T. (1966), The Hidden Dimention. Garden City, New York.

Jones, Louise. (2008), Environmentally Responsible Design, Green and Sustainable Design for Interior Designers. John Wiley \& Sons. Inc, New Jersey.

Duc Huynh, Toan Luu . (2020), The COVID-19 containment in Vietnam - What are we doing. researchgate.net

Markas Besar Kepolisian Republik Indonesia. (2020), Buku Pedoman POLRI Menghadapi COVID-19. Markas Besar Kepolisian Republik Indonesia.

Miller, Robert. (2020), The Wuhan Coronavirus: Survival manual and Concise Guide To COVID19. Robert Miller Publishing.

Moleong, Lexy J. (2009), Metodologi Penelitian Kualitatif, Edisi Revisi, PT Remaja Rosdakarya, Bandung.

Punch, K.F (2006), Developing Effective Research Proposals, London: Sage Publications. RAAP

Olivier Johannes. (2015), Kota Djawa Tempo Doeloe, Gramedia, Jakarta.

Rahayu, (2004) Redesain Pasar Ngasem Pada Kawasan Wisata Tamansari Yogyakarta. Undergraduate thesis, Jurusan Arsitektur Fakultas Teknik Undip.

Soedarsono, RM. (1999), Metodologi Penelitian Seni Pertunjukan dan Seni Rupa, Masyarakat Seni Pertunjukan Indonesia Bekerjasama dengan Arti, Lina atas bantuan Ford Foundation, Bandung.

Sutrisno, Hadi. (1980), Metodologi Research II, Fakultas Psikologi UGM, Yogyakarta.

Yin, R.K. (2008), Case Study Research: Design and Methods, London: Sage Publications.

https://bnpb.go.id/berita/presiden-tetapkan-covid19-sebagai-bencana-nasional. 
Lintas Ruang: Jurnal Pengetahuan \& Perancangan Desain Interior | Vol.8 No.1 2020 | Hal 1-7 